\author{
International Journal of Management Science and \\ Business Administration \\ Volume 5, Issue 2, January 2019, Pages 13-29 \\ DOI: $10.18775 /$ ijms ba.1849-5664-5419.2014.52.1002 \\ URL: http://dx.doi.org/10.18775/ijmsba.1849-5664-5419.2014.52.1002
}

\title{
Creating Global ETF Portfolio with Considering US Market
}

\author{
Bijoy Chandra Das \\ Assistant Professor, Department of Finance \& Banking, Jatiya Kabi Kazi Nazrul Islam University, \\ Bangladesh
}

\begin{abstract}
I have created a global portfolio considering ETFs that will outperform S\&P 500 over the next six months. Firstly, I present the economic conditions of the US and other important developed countries along with emerging countries. Secondly, I consider the present markets of the globe and comments on the situations that what can be happened next six months. Finally, the decision is taken based on the analysis of global growth, GDP across the countries, inflation, interest rates, and unemployment rates to determine the strategic as set allocation for different asset classes.
\end{abstract}

Keywords: ETF, GDP, Inflation, Risk, Emerging market.

\section{Introduction}

The main objective of this paper is creating a portfolio encompassed solely of ETFs that will outperform S\&P 500 over the next six months. The final decision is taken based on the analysis of global growth, GDP across the countries, inflation, interest rates, and unemployment rates. I have analyzed the economic conditions across the globe and different asset classes to determine the strategic as set allocation for different as set classes.

\subsection{European Union and the UK}

Considering the European Union forecast and the growth rate of EU, this area beat the expectation in 2017 as the transition from economic recovery to expansion countries. The economic growth of the European Union and Eurozone in 2017 was estimated to be $2.8 \%$ (estimated is $2.4 \%$ ), it was the highest ever recorded in the decade. Although in July 2018, it's slightly slow down to $2.2 \%$.

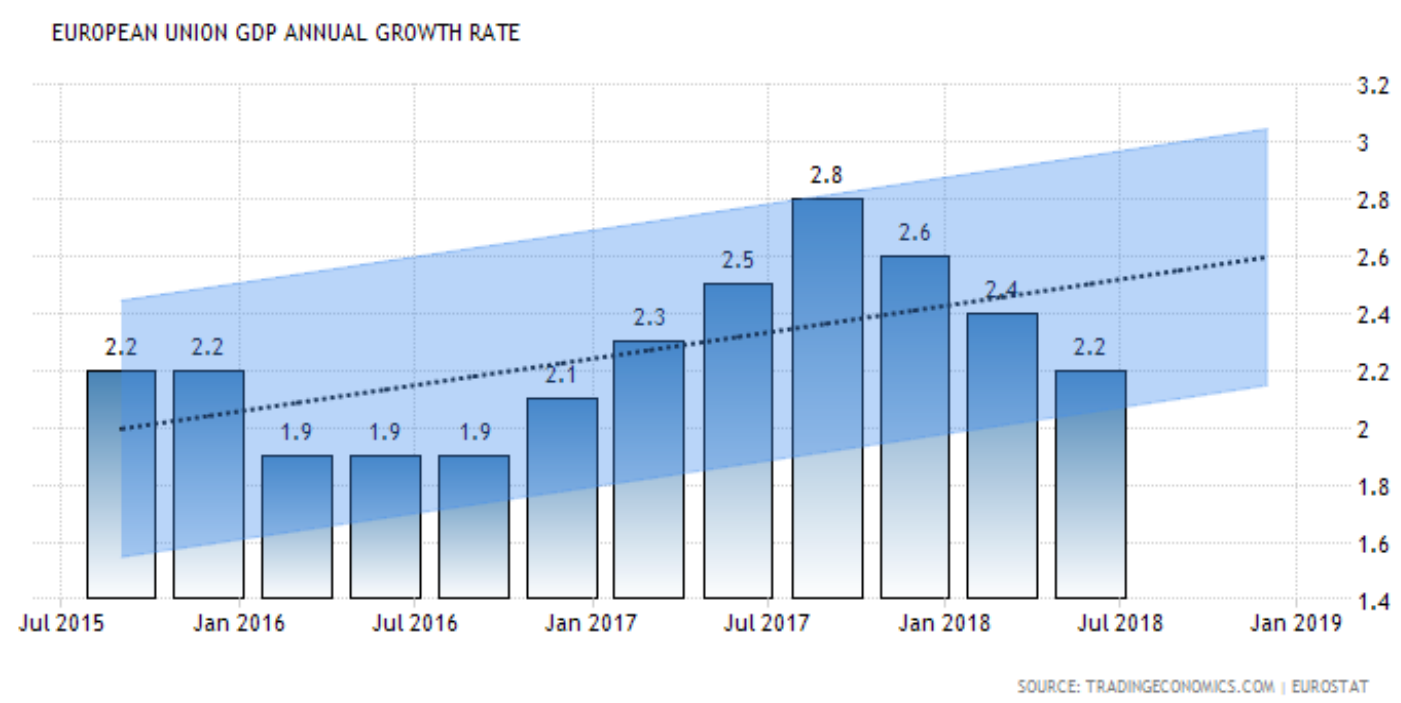

From this graph, it is easily understood that the estimation of the growth will continue in 2018, 2019 as well as 2020 with the growth of $2 \%, 2 \%$ as well as $2.3 \%$ respectively. The forecasts for growth in both EU and eurozone in 2019 have also been raised from $2 \%$ to $2.2 \%$. This is a result of both stronger cyclical momentums in Europe, where labor markets 
continue to improve and economic sentiment is particularly high, and a stronger than expected pick-up in global economic activity and trade. A stronger labor market should support robust growth as the common-currency bloc puts the crisis behind it. However, slower exports growth should take a bite out of the momentum.

In 2017, inflation was recorded at 1.4\%. It is estimated at 1.8\% in Q4/18 and predicted to be $1.7 \%$ in 2019. The economic growth could exceed the expectation in the short term and the global assets could be vulnerable. So, it cannot be neglected the downside risk of the uncertain outcome of Brexit negotiations.

\begin{tabular}{|llllllll|}
\hline Overview & Actual & Q2/18 & Q3/18 & Q4/18 & Q1/19 & $\mathbf{2 0 2 0}$ \\
\hline GDP Growth Rate & 0.60 & 0.5 & 0.5 & 0.6 & 0.8 & 0.7 & percent \\
\hline Unemployment Rate & 8.50 & 8.5 & 8.3 & 8.2 & 8.1 & 7.2 & percent \\
\hline Inflation Rate & 1.40 & 1.4 & 1.5 & 1.8 & 1.7 & 2.1 & percent \\
\hline Interest Rate & 0.00 & 0 & 0 & 0.25 & 0.25 & 0.75 & percent \\
\hline
\end{tabular}

The current coalition government of Germany-greatest economy in eurozone ensured the political stability in the whole country and the coalition's proposed fiscal stimulus should propel private and government consumption this year. The external demand and fixed investment are also expected to be the same strength. It is estimated that GDP is expanding at $2 \%$ in 2018, almost unchanged from last month's estimate, and 2.3\% in 2019. Retail sales and industrial production contracted in January over this time but still showed robust expansion in annual terms.

The political situation in Spain has become more tempestuous in recently. It has increased the uncertainty in this region. There were clashes between regional authorities and the central government because of the independence movement in Catalonia. Intensifying tensions along with public demonstrations could take a ring on economic activity in the region and if not handled properly, it may affect economic growth of the country thereby affecting the economic activities of the other neighboring countries as well. GDP of the UK is expected to slow down in 2018 as public spending cuts and the overall economy may be uncertain because of Brexit. In the UK, the unemployment rate decreased to 4 percent to June 2018, which is the lowest since December 1974. The inflation rate is increased to 2.5 percent which is lower than the previous year's market expectations. At that time, the cost of transport, housing, foods, utilities, and recreations was increased. Total investment and total exports are increased with increased global growth. The Bank Rate is increased to 0.75 percent and the labor market and wage growth have continued to tighten.

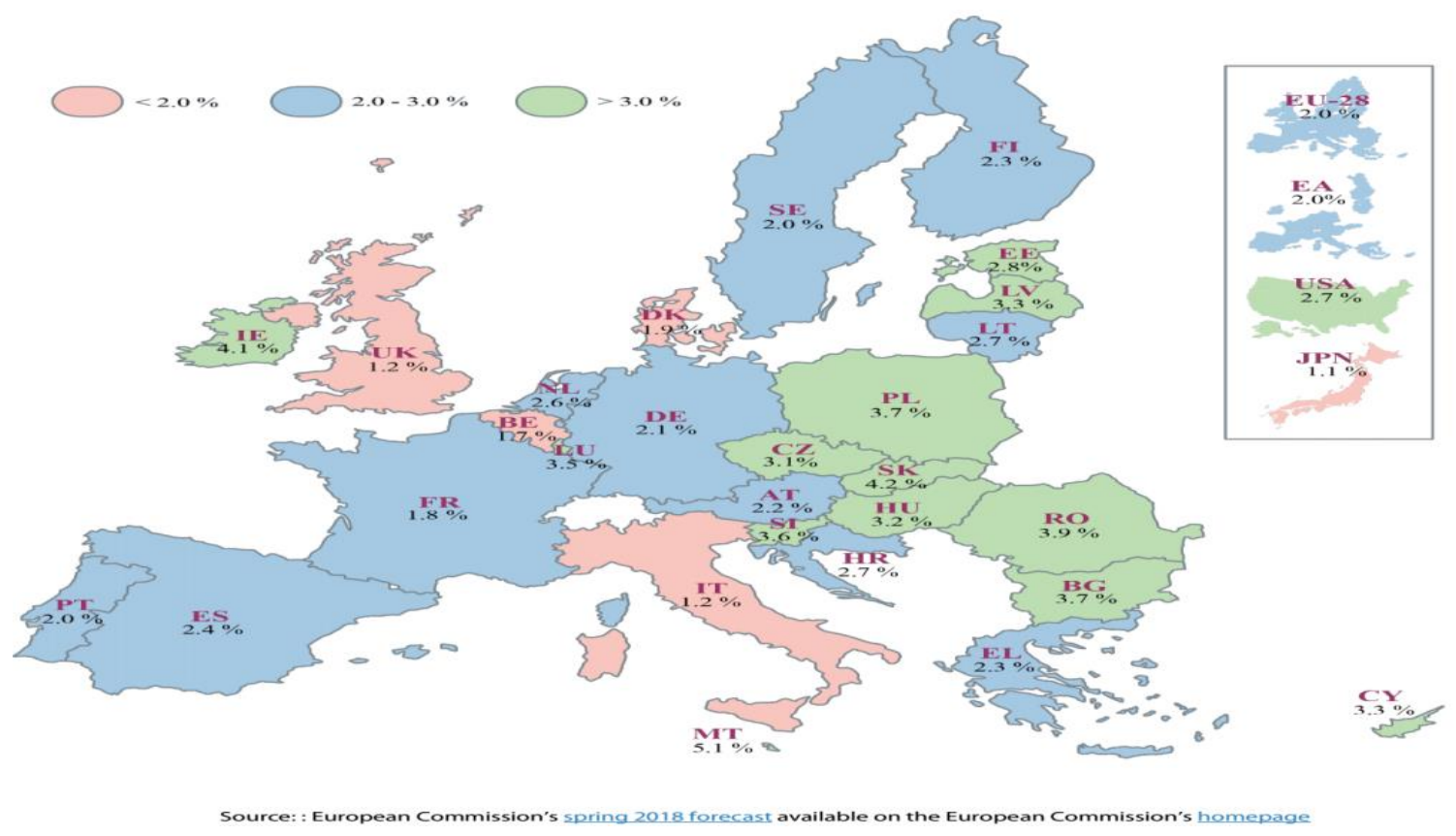

In France, the economy is set to grow at a strong rate in 2018 and 2019 on the back of elevated fixed investment and healthy private consumption. The Focus Economics Consensus Forecast expect that the GDP to grow 2.1\% in 2018, 
which is unchanged from last month's forecast but it is overall higher than the growth of $1.8 \%$ in 2017 , and further, it will expand by $1.9 \%$ in 2019. As a result of a better economy, the unemployment rate will decrease to 9.1 percent in the second quarter of 2018 from 9.2 percent in the previous period and below market expectations of 9.2 percent and inflation is set to remain at 2.3 percent year-on-year in August 2018, unchanged from the previous month's near 6-1/2-year high, a preliminary estimate showed. A slowdown in energy inflation was offset by a further increase in food prices.

\subsection{Russia and Eastem Asia}

Russia's gross domestic product grew by 1.8 percent year-on-year in the second quarter of 2018, following a 1.3 percent expansion reported in the previous period, a preliminary estimate showed. It was the seventh straight quarter of growth after two years of contraction driven by services on the back of the soccer World Cup, in particular, the hotel, transport, and restaurant sectors. Policymakers expect annualinflation to be 3.5-4 percent in late 2018 and to temporarily overshoot 4 percent in 2019, before returning to 4 percent in early 2020 .

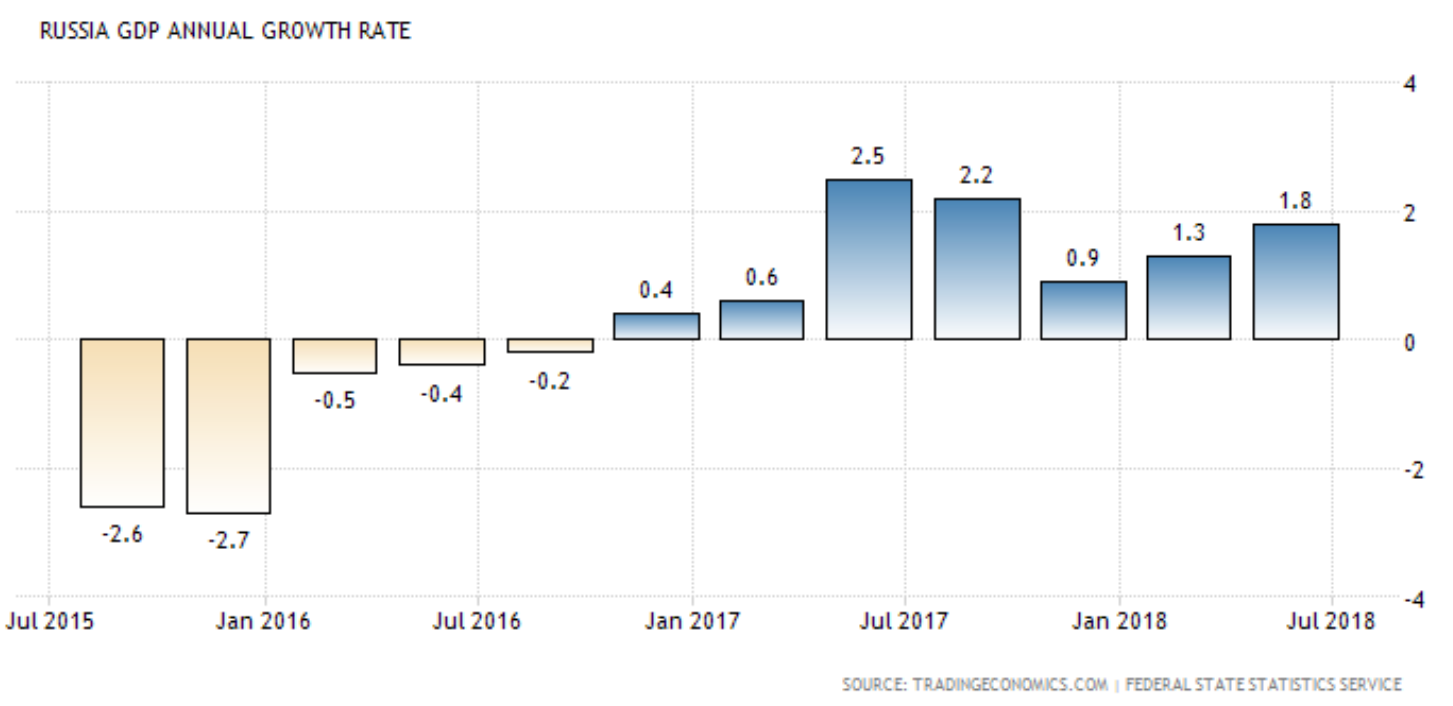

The Turkish economy grew by 7.4\% year-on-year in the first quarter of 2018, following a 7.3 percent expansion in the previous three-month period and beating market expectations of 7 percent. Household consumption and fixed investment rose at a faster pace while net trade contributed negatively to GDP growth, due to a jump in imports. The $7.4 \%$ rate made Turkey the second fastest-growing economy in the Organization for Economic Cooperation and Development after Ireland with $7.8 \%$ and ahead of Slovenia with 5\%. However, dramatic depreciation in Turkish Lira the dollar value of the GDP has decreased to $\$ 851$ billion as compared to $\$ 863$ billion in 2016 . The continued depreciation in Lira may be the matter of concern for Turkey.

\subsection{The Middle East and Africa}

The Middle East and North Africa are suffered from oil production cuts and continued geopolitical tensions. The GDP estimated to have slowed sharply to $1.8 \%$ in 2017 from $5 \%$ the yearbefore. Because of oil cut, economic growth slowed down among the members of Gulf Cooperation Council. Growth in Saudi Arabia fell to 0.3 percent in 2017 from 1.7 due to oil production cuts and fiscal consolidation, and the United Arab Emirates eased to 1.4 percent. The diplomatic rift between Qatar and neighboring economies is estimated to have weighed some what on Qatar's economy, but the impact on neighboring economies has been limited. After an exceptionally high growth rate in 2016 due to the lifting of sanctions, growth in the Islamic Republic of Iran moderated in 2017, contributing sizably to the moderation in regional growth.

Among all the oil importer countries of this region, the Arab Republic of Egypt's growth remained broadly stable at $4.2 \%$ in the fiscal year 2017. An exchange rate devaluation had a positive impact on competitiveness in that country, contributing to strong industrial production, investment, and exports in the second half of the fiscal year. Morocco's growth jumped to a $4.1 \%$ rate on a strong rebound in agricultural production. GDP Growth in the region is expected to rise to 3 percent in 2018 and 3.2 percent in 2019, assuming a moderation of geopolitical tensions and a modest rise in oil prices. GCC economies are anticipated to lead stronger growth in the region, supported by easing the fiscal adjustment, 
infrastructure investment such as the UAE Expo 2020, and reforms to promote non-oil sector activity. Growth among the GCC countries as a group is forecast to pick up to 2 percent this year from 0.7 percent in the year.

Saudi Arabia is the world's biggest producer of oil and oil extraction accounts for 46 percent of GDP. The services sector represents 36 percent of the wealth including government services (13 percent), wholesale and retail trade and restaurants and hotels (8 percent) and financing, insurance and real estate ( 7.9 percent). Other sectors are manufacturing (10 percent), construction and electricity, gas and water distribution (6 percent) and agriculture, forestry and fishing (2 percent). Growth in Saudi Arabia, the largest economy in the Middle East is anticipated to advance to 1.6 percent as recently predicted IMF. It has negative growth last year due to heavy cut in oil production because of the falling oil price. The Is lamic Republic of Iran, the second largest economy in the region, GDP is expanded by $2.7 \%$ in the first quarter of 2018.

SAUDI ARABIA GDP ANNUAL GROWTH RATE

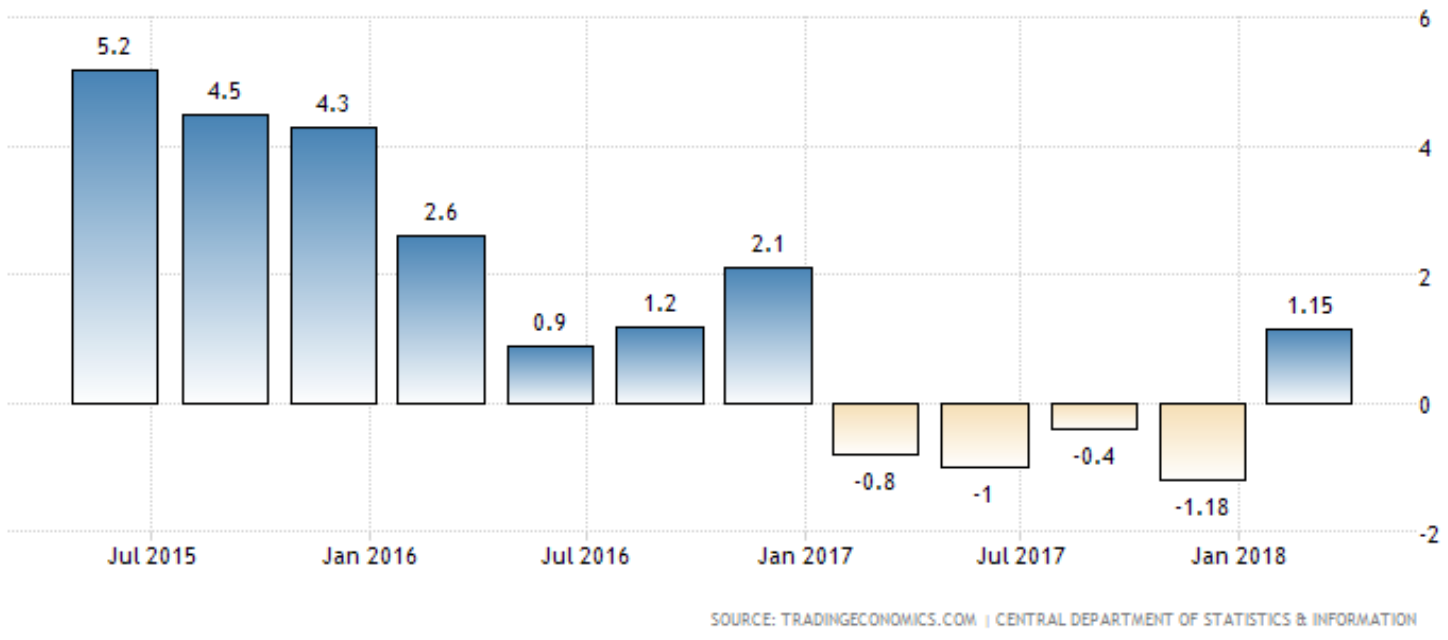

The business and consumer confidence are improved by reforms and external demand of customers improve at the time of growth among some oil importers in the region in 2018. Egypt's economy is expected to grow by $4.5 \%$ in 2018 as ongoing reforms and an improved business climate. The diplomatic and geopolitical tension in the Middle East including Libya, Syria, Republic of Yemen etc. make the overall economic activities vulnerable which may be the cause for slow economic growth in the region.

The Middle East and North Africa (MENA) economies seek to adapt to the consequences of six years of economic and financial hardships emanating from falling global oil prices and ongoing wars. Wide-ranging measures were taken to control public finances, improve the investment climate, boost social safety nets as well as diversify economic partnerships and increase capital spending.

Although these measures would have a relatively positive impact in 2019, the performance of the region's economies will remain vulnerable to several risks due to armed conflicts, refugee crises as well as potential protests over social grievances and failure of some governments to achieve reasonable economic performance.

\subsection{Asia}

In Asia, I will mainly focus on Indian, Chinese and Japanese economy for my analysis.

\subsubsection{India}

Indian economic data remains largely encouraging, with GDP growth picking up more than expected. The robust GDP print reflected higher government consumption growth and increased public capital outlays, which more than offset a moderation in private spending growth. A cyclical economic recovery has taken hold as the effects of demonetization and the Goods and Services Tax. Unemployment Rate in India is expected to be 3.50 percent by the end of this quarter, and forecasted Unemployment Rate is projected to trend around 3.60 percent in 2020. I can expect the growth of $7.6 \%$ in FY 2018, which is unchanged from last month's estimate. In FY 2019, it has a forecasted GDP expansion of 7.5\%. 


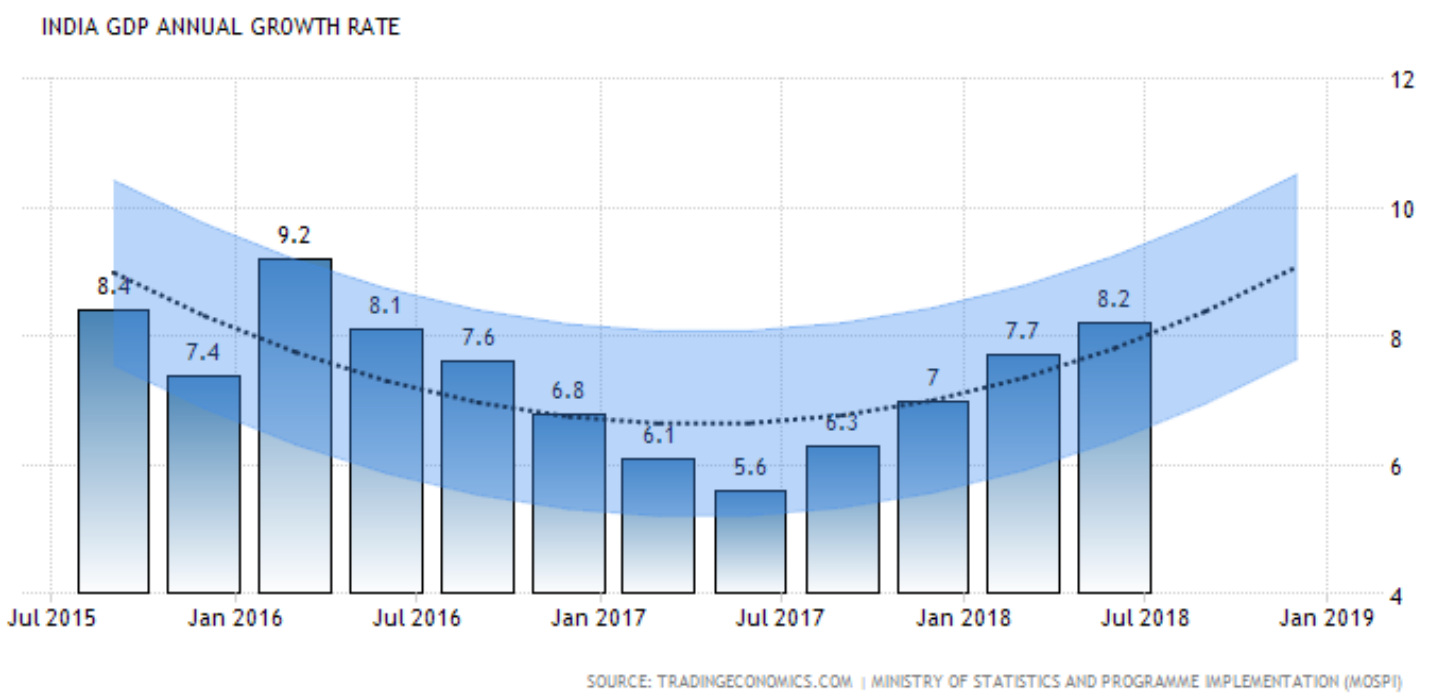

\subsubsection{China}

Moving on to the Chinese economy which is successfully moving towards more sustainable growth levels but the risks from a potential trade war with the U.S. are clouding the economic outlook for China. Moreover, tighter financial conditions to ensure financial deleveraging could dent domestic economic activity. The economy is said to grow by $6.6 \%$ in 2018 and the forecast GDP in 2019, is expected to grow by $6.5 \%$.

CHINA GDP ANNUAL GROWTH RATE

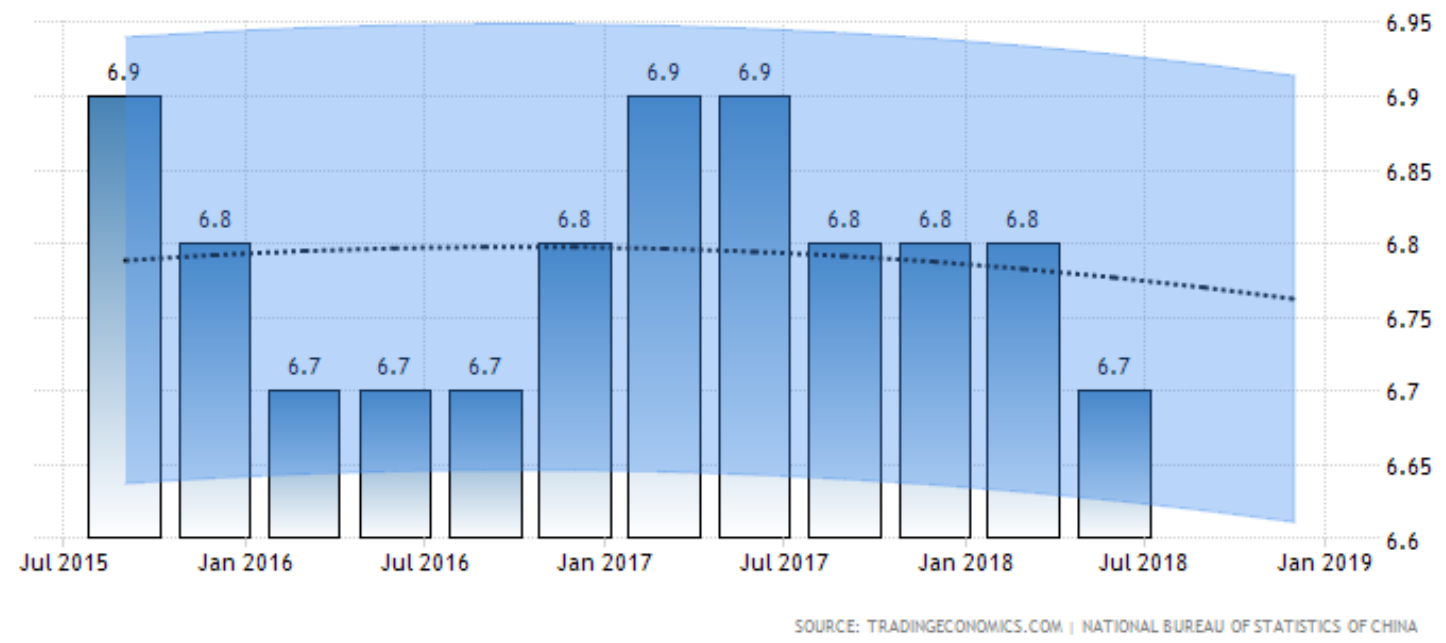

Unemployment Rate in China is expected to be $4 \%$ and estimated to be 3.90 in 2019. The forecasted unemployment rate is expected to be around 5.00 percent in 2020.

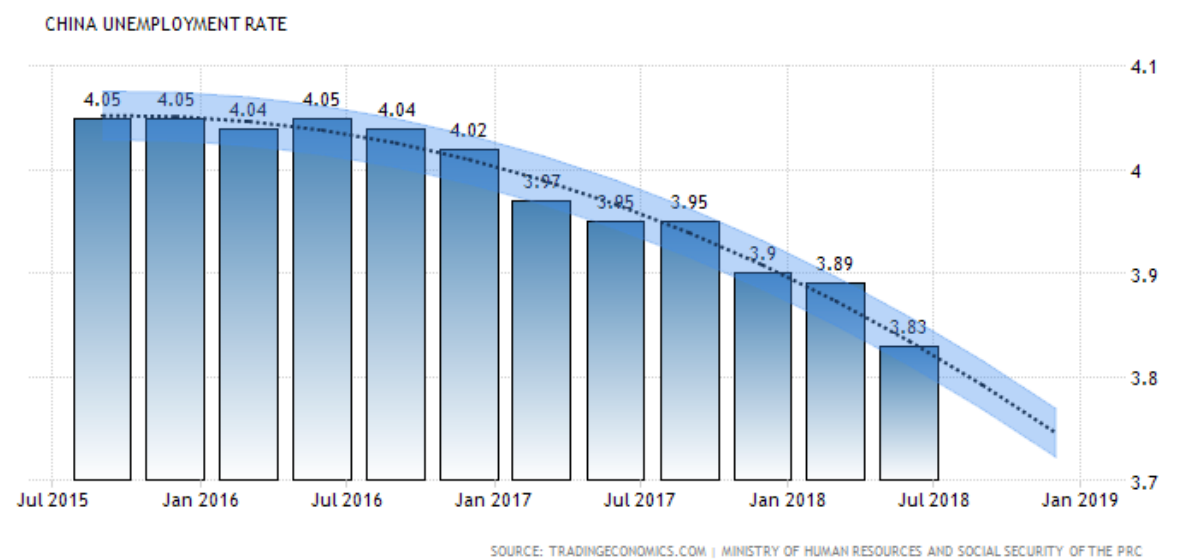




\subsubsection{Japan}

The Japanese economy has been facing deflationary pressure for quite long-term. The recent volatility in Japanese Yen after the Brexit hurt the exporters. The unemployment decreased to an over two-decade low. On the political side, the news of the corruption related to the prime minister and his wife came up in March. The main reason for the slowdown is the slowdown in China which is the key trading partner for Japan. The economy is growing at 1.5\% in 2018, which will be unchanged in 2019. Unemployment Rate in Japan is expected to be $2.3 \%$ by the end of this quarter. Forecasted Japan Unemployment Rate is projected to trend around 2.3\% in 2019 and 2.8\% in 2020.

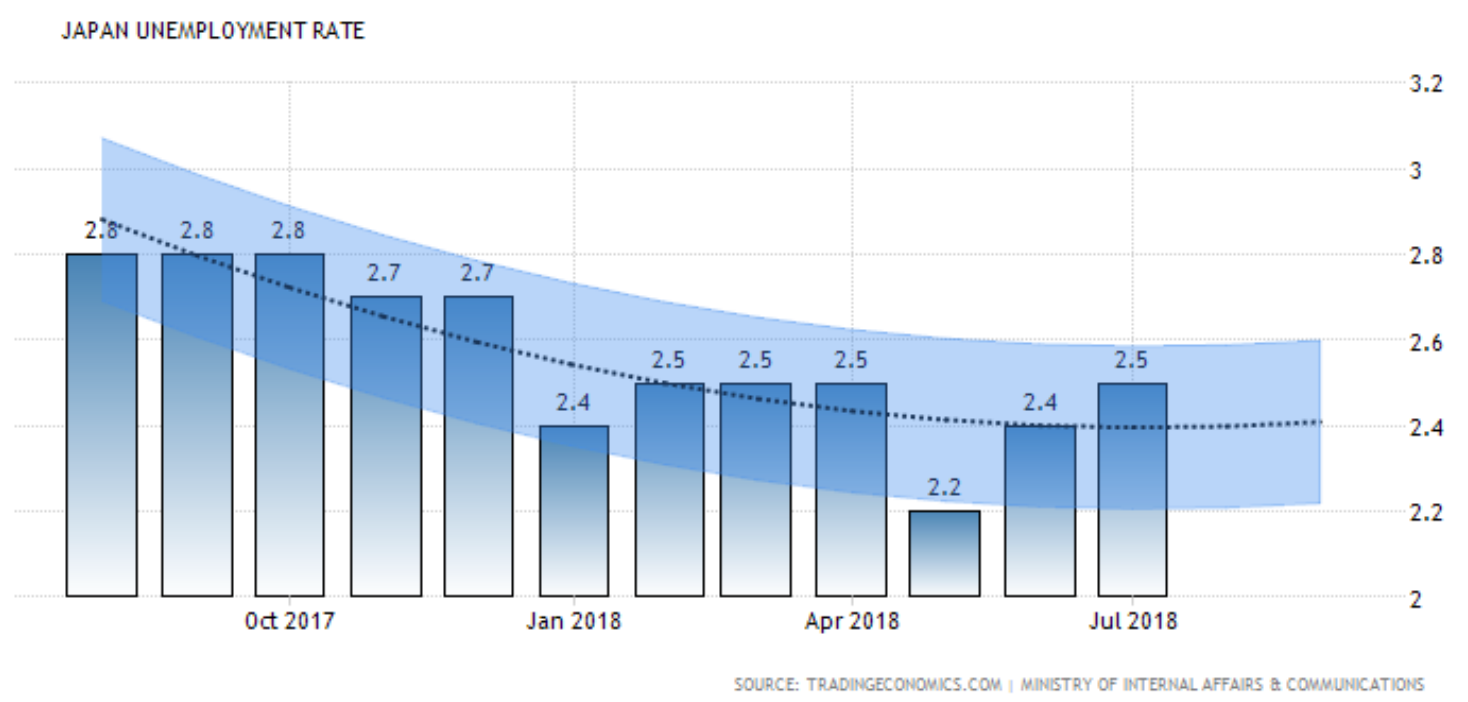

\subsection{USA}

At a time when the US economy is already bustling, U.S. tax refurbishment and public spending plans amplified growth and earnings guesses of U.S. equities at the end of 2017. All major indexes such as S\&P 500, Dow Jones, Russel2K and NASDAQ set the all-time high records at the beginning of 2018. This adds the potential for greater productivity growth and business spending as well as the risk of overheating the economy. Inflation is moving back to the target, giving confidence that the Federal Reserve will likely forge ahead with rising rates. I favor U.S. equities and emerging markets equities, but I see higher volatility than last year ahead. The major risk for U.S. economic expansion for the next six months would be rising fears of a trade war and spike in real yields.

\subsubsection{GDP Growth}

The United States is the world's largest economy. Yet, in the last two decades, like in the case of many other developed nations, its growth rates have been decreasing. If in the '50s and 60's the average growth rate was above 4 percent, in the '70s and 80's dropped to around 3 percent. In the last ten years, the average rate has been below 2 percent and since the second quarter of 2000 has never reached the 5 percent level. The Gross Domestic Product (GDP) in the United States expanded $2.90 \%$ in the second quarter of 2018 over the same quarter of the previous year. For the next 6 months, I see a steady growth rate.

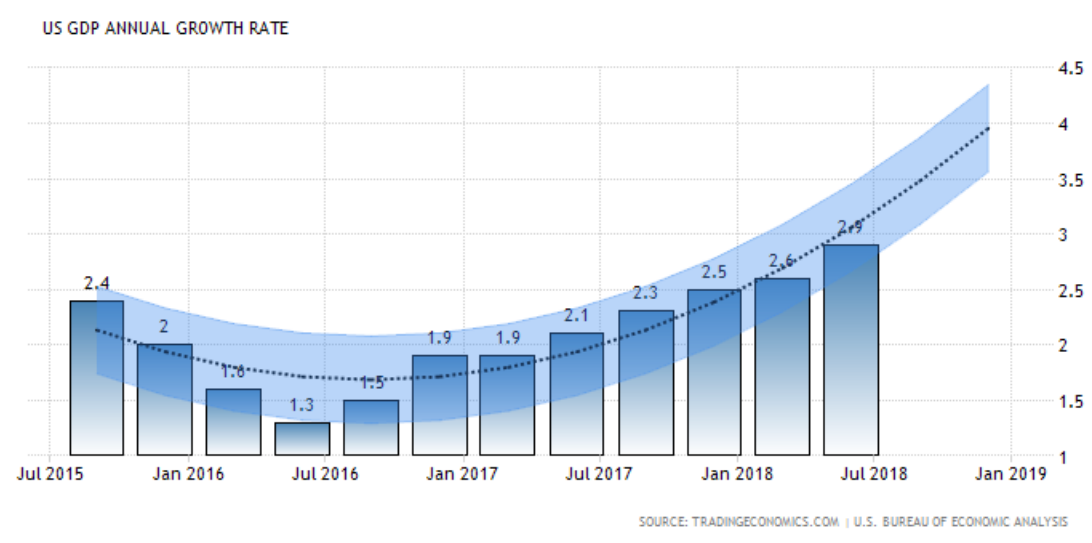




\subsubsection{Inflation}

US annual inflation rate stood at 2.9 percent in July 2018, unchanged from the previous mon th and slightly below market expectations of 3 percent. Main upward pressure came from: fuel oil (34.7 percent vs 30.8 percent); gasoline (25.4 percent from 24.3 percent); shelter ( 3.5 percent vs 3.4 percent); transportation services (4 percent vs 3.7 percent); used cars and trucks ( 0.8 percent vs -0.7 percent); and new vehicles ( 0.2 percent vs -0.5 percent). Meanwhile, food inflation was unchanged at 1.4 percent, while prices rose at a softer pace for medical care services (2.3 percent vs 2.5 percent); app arel ( 0.3 percent vs 0.6 percent); and medical care commodities ( 0.4 percent vs 2.4 percent). Also, prices continued to drop for both electricity ( -0.8 percent vs -0.1 percent) and utility piped gas service ( -1.3 percent vs -2.1 percent). Core inflation, which excludes food and energy, rose to 2.4 percent in July from 2.3 percent in June. It was the highest rate since September 2008.

U.S. Inflation GPS has consumer price inflation near 2.4\% as of March 2018. U.S. inflation is moving back to the target of $2 \%$. The rising interest rate has been carefully watched by investors. As inflation has peaked up, Federal Reserve is on track to raise rates. I do not see inflation rising far above $2 \%$, but the risks are now two ways after years of deflation fear to dominate. Since markets have caught up with Fed's pace of rate increases in 2018, I see at least two times rate hike in 2018 due to robust growth and moderately rising inflation.

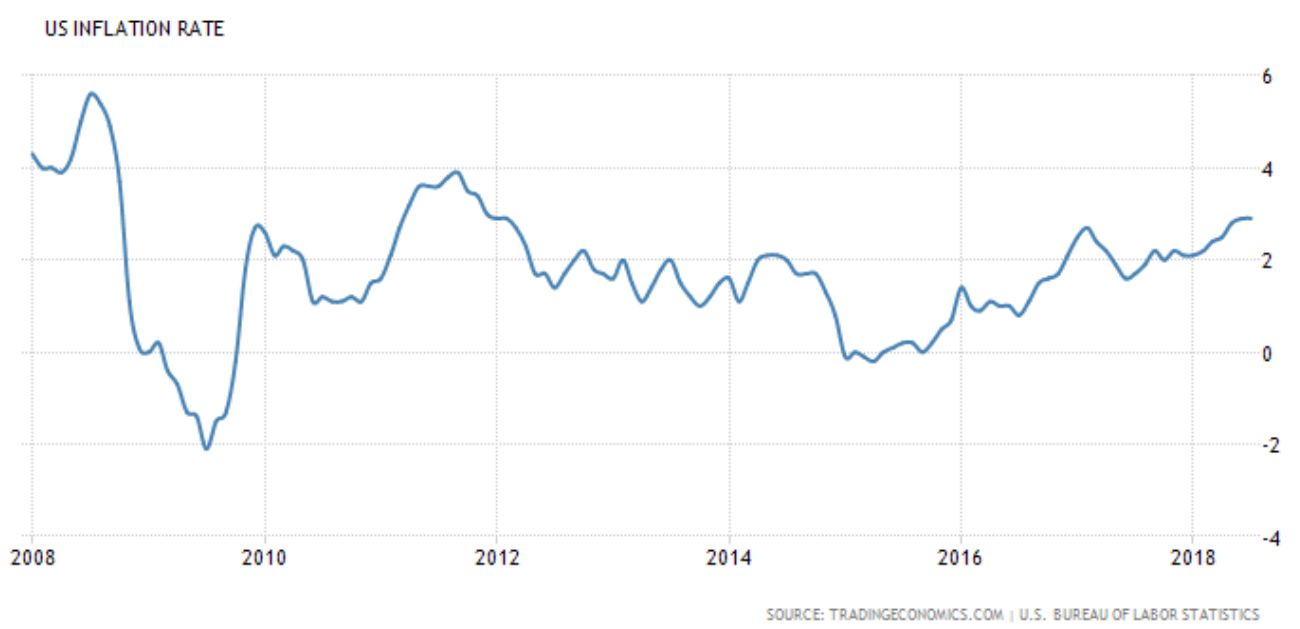

\subsubsection{Unemployment}

According to trading economics global macro models and analysts, the unemployment rate in the US is projected to be 3.90 percent in 2019. In the future, I guess that the unemployment rate in the US will be 3.80 percent at the end of 2019. In the long run, the US unemployment rate is estimated to be around 4.50 percent in 2020.

US UNEMPLOYMENT RATE

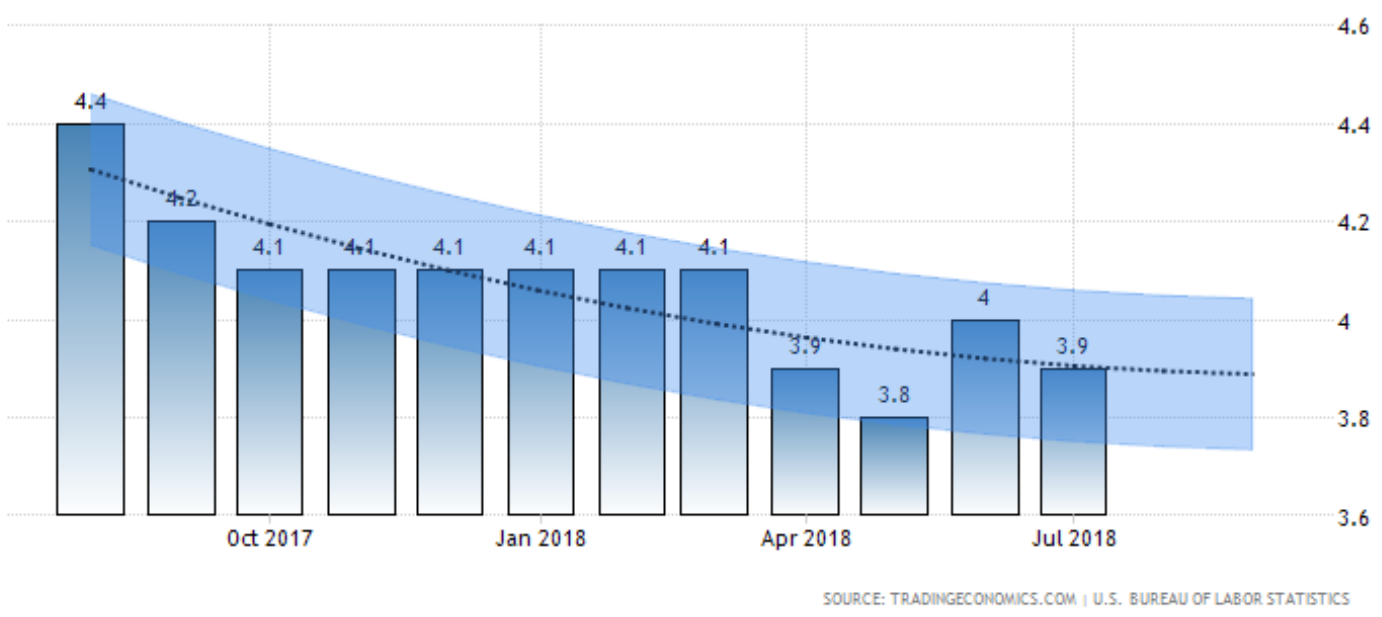




\subsubsection{U.S. Earnings Momentum}

With the government tax cuts and government public spending plans, this is the U.S. fiscal stimulus coming outside of a recession in decades. Earnings growth is gaining momentum on the back of economic strength. It is further fueled by US spending and tax plans. Dividends payout \& share buybacks are another support to earning to economic expansion as companies look to deploy their tax windfalls. As it can be shown from the chart below, the U.S. earning momentum is very strong, thus making equity look appealing. With earnings growth, it's shown returns of capital to shareholders offsetting some risks of rising interest rates and inflation.

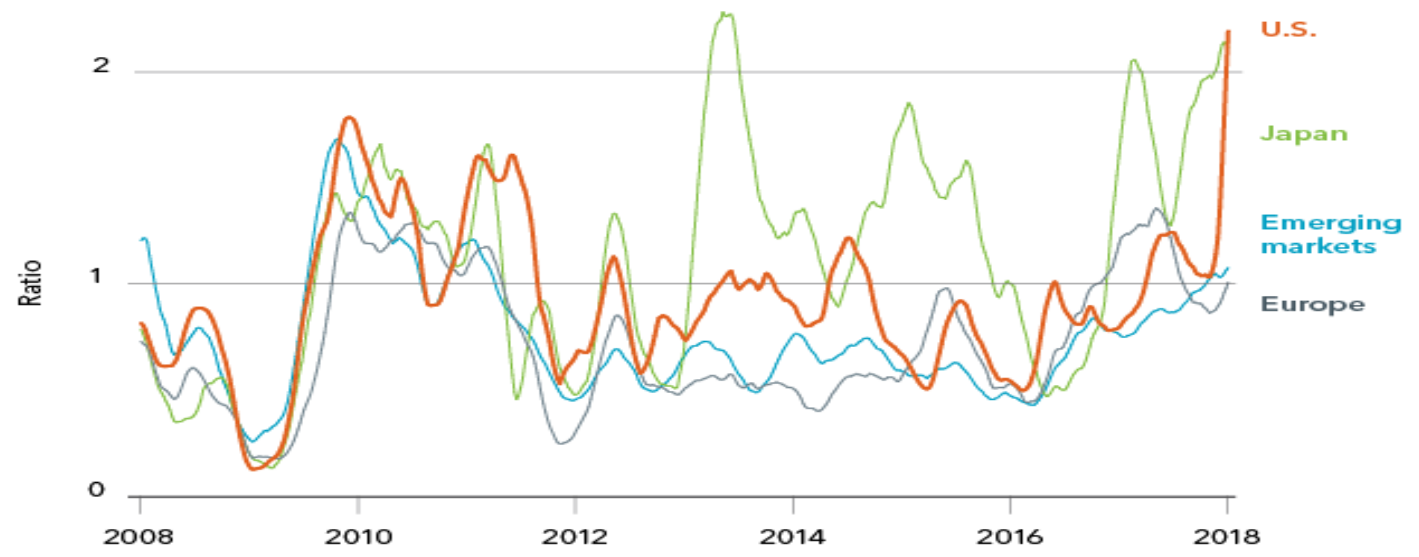

\subsubsection{Risks}

Risk arises with the trade war between the United States and China heated up following the U.S announce ment of tariff on imports of 60 billion worth of Chinese goods and services. Although the total tariff target from China is $\$ 200$ billion (September 2018). The U.S. Protectionism policy has already prompted threats of retaliation. I view two sides will choose a deal over a trade war. Tariffs might yet be avoided by China agreeing to buy more American stuff and trying to address its trade deficits with the U.S. by opening its markets. For the next six months trade war is a big risk.

\subsubsection{Vix}

After a very strong year for equity market in 2017, I saw stocks stumbled at the first hurdle heading in February. A brief recovery of stocks in the latter part of February was interrupted again in March by concerns over potential trade war between the USA and China. September is usually bad for stocks and even worse in midterm election years. I also see that stocks stumbled in November. Topping the list of threats to a market rally are more U.S. tariffs on Chinese goods, the Fed raising rates, and midterm elections. Traders have been betting against the CBOE Volatility Index, a popular gauge of market fear that goes up when the stockmarket falls. In the early December market may comeback that virtually may cut October's losses in half.

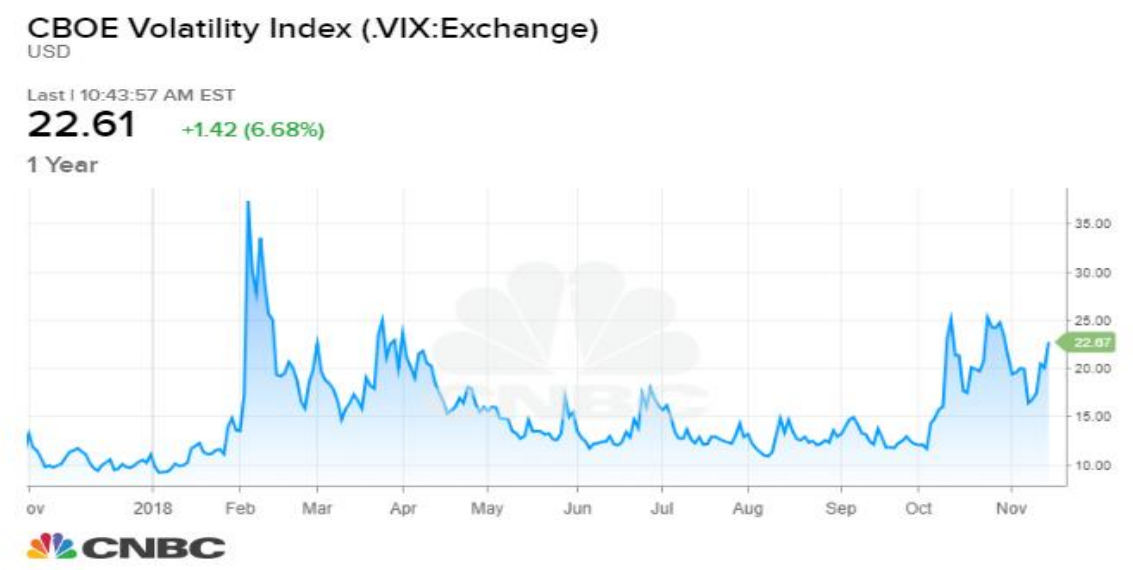


The rushing of the wage growth increases the worry of investors that the interest rate of the US may rise faster than the economy could endure, causing investors to run for speed. Just as it appeared that the calm has returned to the market, global equities tumbled once again by the fear of global trade war. At the beginning of the year, I saw greater volatility in markets and still, it's continuing. However, having strong fundamentals, healthy global growth and accommodative monetary policy, equity market outlook for the next six months looks appealing.

\section{Asset Classes}

\subsection{Equity}

According to the experts, the present economy of the US is healthy but not robust because the growth rate of GDP will be slightly below $3 \%$. The unemployment rate may continue at a natural level. There may not have too much inflation or deflation.

\section{Small Cap vs. Large Cap:}

When I had to choose between a large cap and small cap companies for my portfolio, I would go with the small cap as mostly the large multinational companies do a significant amount of their businesses outside of the US. These businesses will face currency headwinds from overseas operations when there is a hike in the FED, which is likely to be hiked four times in the current years. Considering the above reason, I am recommending Small Cap funds such as Vanguard SmallCap Index Fund (VB).

\section{Recommended}

The Vanguard Small Cap ETF which tracks the investment of the small caps. That is, these firms are likely to provide strong growth prospects to a portfolio and should have a much easier time growing then their large-cap counterparts. This ETF focuses on both value and growth securities, could provide more of a diversified play than products that just focus on 'growth' or 'value' securities within this segment and it mostly focuses on sectors like Technology, Industry, and Finance which are the best sectors to invest.

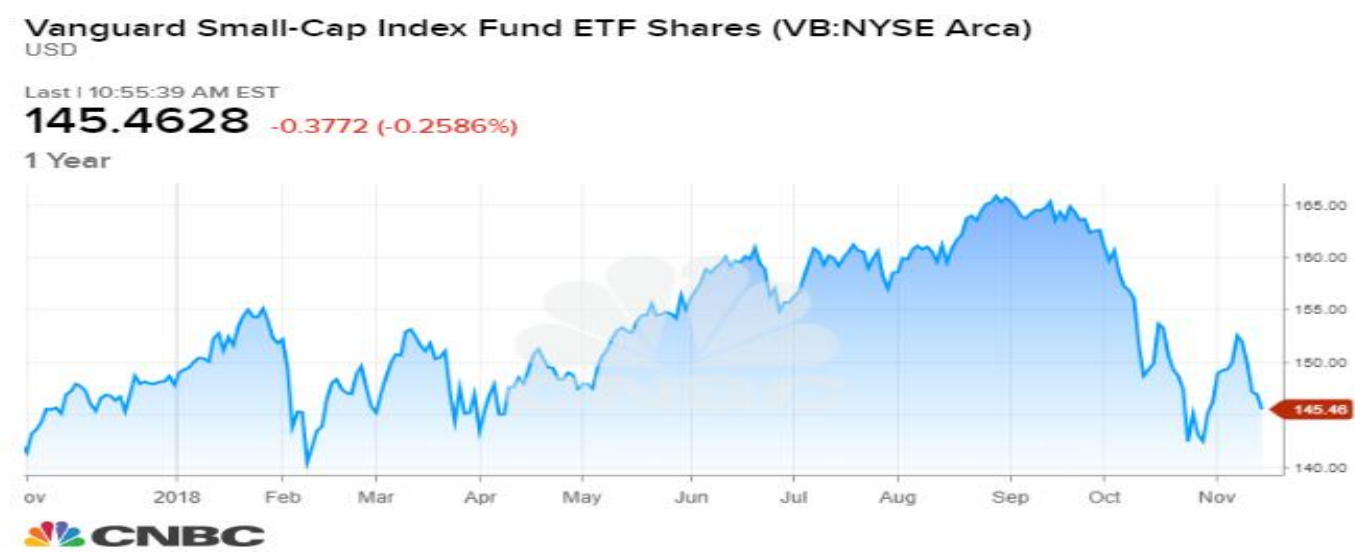

\section{Growth vs Value:}

Over the next six months, I believe investing only on growth stocks or investing only on value stocks will not work in my favor, so I decided to invest in both growth and value sectorby investing in higher yielding sectors such as finance and technology. One of the main reason for this investment is that, in recovery mode like the US is currently in right now the value-oriented sector is to outperform and the growth bonds are also a good fit in the portfolio as the yields in treasury are increasing significantly from the start of the year.

\section{Recommendation 1: Vanguard Mega Cap Growth ETF (MGK) (Growth)}

a. This ETF offers exposure to large-cap companies within the growth sector of the domestic equity market

b. Companies within the growth segment offer tremendous profit potential since they are still in the early stages of their life cycle

c. The Annual Total Return increases to $37.47 \%$ in 2017 from $6.29 \%$ which signifies good returns

d. It has a significant low expense ratio of $0.07 \%$ and a good P/E ratio of $28.99 \%$. 


\section{Recommendation 2: Vanguard Mid-Cap Value ETF (Value)}

The low expense ratio of $0.07 \%$ and a good $\mathrm{P} / \mathrm{E}$ ratio of $24.63 \%$

Doesn't stray into small-caps as many peers do, although it does emphasize different sectors

The fund's liquidity is among the best in its segment and as the graph displays the ETF top sectors are the highest yielding sectors.

\section{Sector Breakdown}
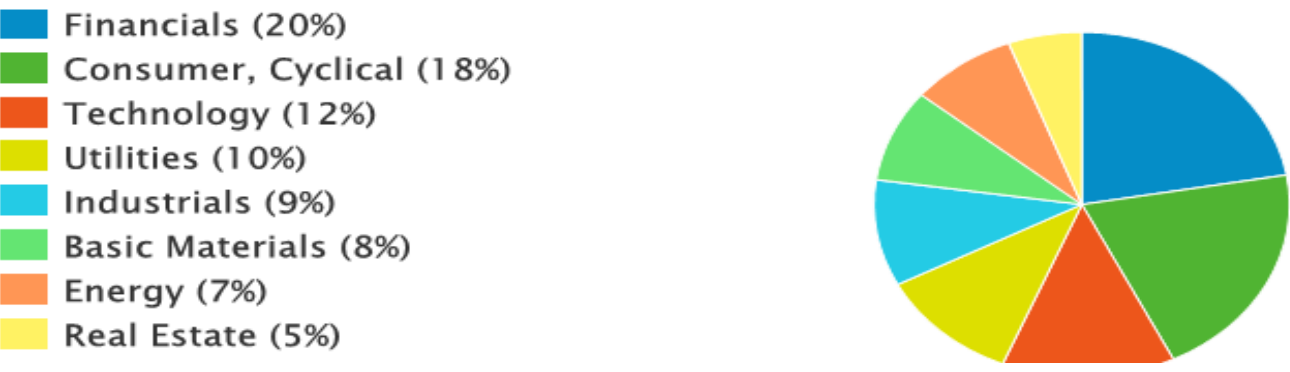

\section{Not recommended}

The lowest yielding sectors are the Utilities, Real Estate and Telecommunication. As the yield and retunes are low I do not recommend the below ETF's

a. Utilities Select Sector SPDR Fund which mostly concentrates on utility.

b. REITS - An ETF that typically tracks Real estates.

\subsection{Global Asset Allocation}

After analyzing forecasted economic conditions, I proposed two countries. I felt that it would be the most beneficial to include in the portfolio. Furthermore, based on the future economic forecast I proposed two countries that Ibelieve should not be included in the portfolio. And as I am creating a short-term portfolio I would not like to hedge my funds.

\section{Recommendation 1: India ETF- INDA iShares MSCI India ETF}

I recommend INDA iShares MSCI India ETF to be included in the portfolio. My recommendation is based on the following reasons:

a. The Indian economy will grow at $7.6 \%$ in 2018 and $7.5 \%$ in 2019 , making it the fastest-growing major economy in the world.

b. The inflation rate in India is expected at 4.40 percent in 2019

c. Employment rates projected to keep improving (4.9\%) The Unemployment Rate is projected to reduce to $3.60 \%$ in 2020

Since his election in 2014, Prime Minister Modi's government has pushed through a lot of reforms in India. Foreign investors continue to believe he will be able to take necessary actions to promote foreign investments, revamp the tax system, promote infrastructure and reduce corruption. He'll most likely win a second term in office in the next general elections.

\section{Recommendation 2: (Europe) ETF- Vanguard FTSE Europe ETF (VGX)}
a. AUM- \$18.91billion
b. Price / Earnings Ratio- $18.2 \%$
c. Expense Ratio- 0.10

The European economy grew 0.6\% and GDP Growth Rate in Euro Area was 0.80 in 12 months' time. Exports rose 1.9 percent, after a 1.6 percent increase in the third quarter, while imports went up at a slower 1.1 percent, compared with a 0.6 percent gain in Q3. The unemployment rate in the Euro Area edged down to 8.5 percent in February of 2018 from 8.6 percent in January, matching market expectations. 


\section{Not Recommended 1: Pakistan}

The liquidity in PAK can be a challenge with light volume and wide spreads most days. Block liquidity is poor, and institutions should be aware that large orders will affect the underlying market. The consumer price index is $5.8 \%$ easing from $3.80 \%$ from the previous month and is expected to go to $6.50 \%$ in the next 12 months which makes broad market leading to high credit risk. The major is sue is the political problem. There is no political stability which impacts on the economy of the country. So, the economy of PAK may be vulnerable at any time.

\section{Not Recommended 2: Brazil}

Brazil experienced an economic crisis from 2015-2016 where the economy lost more than 1.5 million jobs throughout which kept rising leaving the unemployment rate to $12.46 \%$ in the last three months of 2018. The annual GDP growth was $1 \%$ in July 2018 but inflation was confirmed at $4.19 \%$. I would not recommend investing in this country un til it reaches economic stability.

\subsection{Sectors \& Subsectors}

In the following section, I will analyze the forward outlook of individual sector based on domestic and international macroeconomic factors.

\section{S\&P 500 Sectors Performance}

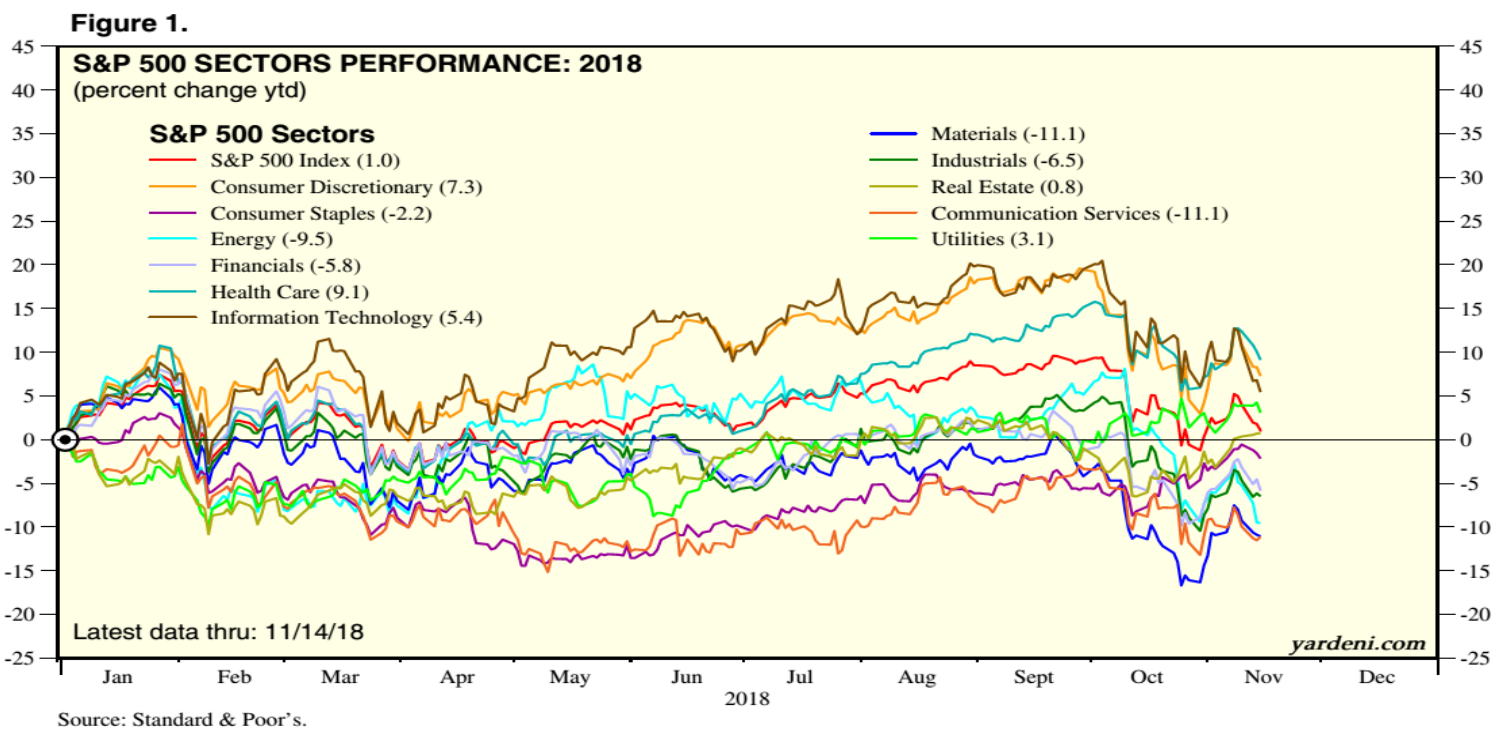

a. Consumer Discretionary

Positive: improved job market, growth in aggregate wages

Negative: fierce competition among retailers (low margin), an unexpected rise in inflation

b. Consumer Staples

Positive: cost-cutting technology, low-commodity prices

Negative: quantitative easing around the world, low-pricing power

c. Energy

Positive: new OPEC deal, flexible regulations in the US, the stable growth rate

Negative: rising dollar, more energy efficient technologies

d. Financials

Positive: improved credit market, low default rate, rising yield curve,

Negative: rates rising unexpectedly, new regulations (trade policy)

\section{e. Healthcare}

Positive: aging population, strong balance-sheet Negative: uncertainty over the Affordable Care Act, Medicare reimbursement, pricing regulations

\section{f. Industrials}

Positive: excess cash in corporations' balance sheet, govt. spending on infrastructures

Negative: higher interest rates, fiscal austerity 


\section{g. Information Technology}

Positive: advanced technology, growth in wages, tax cut

Negative: capital spending delay, fierce competition, increased regulation (Recent example of Facebook, as Mark Zuckerberg, faced congress about the data issue)

\section{h. Materials}

Positive: robust growth in the emerging economy, quantitative easing

Negative: decelerate growth rate in China, higher wage demand

\section{i. Real Estate}

Positive: low mortgage rate, low default rate, high-demand in rentals

Negative: rising rates, shifting to online shopping (low-demands in shopping malls)

\section{j. Utilities}

Positive: attractive dividend payout rates, the strong housing market

Negative: rates rising unexpectedly, new regulations, inflation

After carefully considering various as pects of different sectors described above and the following scoreboard index which shows a positive Fundamentals (ROE, EBITDA, FCF), Relative Valuations (Earnings Yield) and Relative Strength (Performance against S\&P 500) for Information Technology sector and Relative Strength is positive for Financial Sectors, I decided to include Information Technology and Financials Sectors in my portfolio.

\section{Sector Investing: Sector Outlook 2018 - Fidelity}

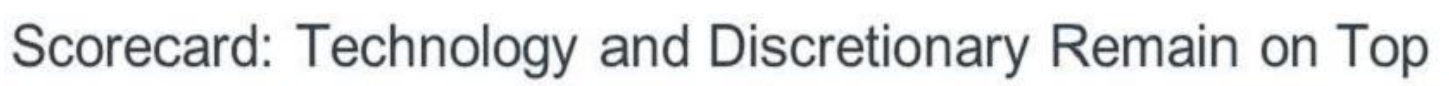

\begin{tabular}{|c|c|c|c|c|c|c|c|c|c|}
\hline \multirow{2}{*}{\multicolumn{2}{|c|}{ Sector }} & \multirow{2}{*}{$\begin{array}{l}\text { Longer } \\
\text { Business } \\
\text { Cycle }\end{array}$} & \multicolumn{2}{|c|}{ Time Horizon View } & \multirow{3}{*}{$\begin{array}{l}\text { Shorter } \\
\text { Relative } \\
\text { Strength } \\
\text { + }\end{array}$} & \multirow{3}{*}{$\begin{array}{l}\text { Weight in } \\
\text { S8P } 500^{\circ} \\
\text { Index } \\
12.9 \%\end{array}$} & \multicolumn{3}{|c|}{ Performance as of $6 / 30 / 18$} \\
\hline & & & Fundamentals & $\begin{array}{l}\text { Relative } \\
\text { Valuations }\end{array}$ & & & \multirow{2}{*}{$\begin{array}{l}\text { Latest } \\
\text { Quarter } \\
8.2 \%\end{array}$} & \multirow{2}{*}{$\begin{array}{l}\begin{array}{c}\text { Year } \\
\text { to Date }\end{array} \\
11.5 \%\end{array}$} & \multirow{2}{*}{$\begin{array}{l}\text { Dividend } \\
\text { Yield } \\
1.2 \%\end{array}$} \\
\hline 8 & $\begin{array}{l}\text { Consumer } \\
\text { Discretionary }\end{array}$ & & + & - & & & & & \\
\hline & Consumer Staples & & & & - & $6.7 \%$ & $-1.5 \%$ & $-8.5 \%$ & $3.1 \%$ \\
\hline & Energy & & & + & + & $6.3 \%$ & $13.5 \%$ & $6.8 \%$ & $2.6 \%$ \\
\hline$\$$ & Financials & & - & + & & $14.2 \%$ & $-3.2 \%$ & $-4.1 \%$ & $1.7 \%$ \\
\hline (4) & Health Care & & & & & $13.9 \%$ & $3.1 \%$ & $1.8 \%$ & $1.6 \%$ \\
\hline & Industrials & + & & - & - & $9.9 \%$ & $-3.2 \%$ & $-4.7 \%$ & $2.0 \%$ \\
\hline & $\begin{array}{l}\text { Information } \\
\text { Technology }\end{array}$ & + & + & - & + & $26.0 \%$ & $7.1 \%$ & $10.9 \%$ & $1.1 \%$ \\
\hline 댐 & Materials & - & + & & & $2.8 \%$ & $2.6 \%$ & $-3.1 \%$ & $2.0 \%$ \\
\hline 요 & RealEstate & & - & & & $2.7 \%$ & $6.1 \%$ & $0.8 \%$ & $3.3 \%$ \\
\hline \& & Telecom & & & + & - & $1.8 \%$ & $-0.9 \%$ & $-8.4 \%$ & $5.2 \%$ \\
\hline 8 & Utilities & - & - & & & $2.8 \%$ & $3.7 \%$ & $0.3 \%$ & $3.4 \%$ \\
\hline & & & & & & $\begin{array}{l}\text { S8P } 500^{\circ} \\
\text { Returns }\end{array}$ & $3.4 \%$ & $2.6 \%$ & $1.8 \%$ \\
\hline
\end{tabular}

\section{Information Technology}
a. Technology leads the market in 2018
b. The likelihood of a prior year's top sector outperforming again in the subsequent year has been mixed historically, but sector leadership sustainability has improved over time.
c. Further, top-performing sectors are unlikely to fall to the bottom three in the following year.
d. Information Technology has consistently beaten S\&P 500 since the end of 2017. 


\section{Recommendation 1: Vanguard Technology ETF}

\begin{tabular}{|lccc|}
\hline Fund & Ticker & YTD Return & $\begin{array}{c}\text { SEC } \\
\text { Yield }\end{array}$ \\
\hline Vanguard Information Technology ETF & VGT & $11.9 \%$ & $1.0 \%$ \\
Vanguard Consumer Discretionary ETF & VCR & $6.7 \%$ & $1.2 \%$ \\
\hline Vanguard Financials ETF & VFH & $6.3 \%$ & $1.7 \%$ \\
\hline Vanguard Health Care ETF & VHT & $5.8 \%$ & $1.4 \%$ \\
\hline Vanguard Industrials ETF & VIS & $2.8 \%$ & $1.6 \%$ \\
\hline Vanguard Materials ETF & VAW & $1.3 \%$ & $1.7 \%$ \\
\hline Vanguard Telecommunication Services ETF & VOX & $-1.7 \%$ & $3.7 \%$ \\
Vanguard Consumer Staples ETF & VDC & $-3.7 \%$ & $2.6 \%$ \\
Vanguard Energy ETF & VDE & $-5.4 \%$ & $2.7 \%$ \\
\hline Vanguard Utilities ETF & VPU & $-6.4 \%$ & $3.5 \%$ \\
\hline Vanguard Real Estate ETF & VNQ & $-6.9 \%$ & $3.8 \%$ \\
\hline
\end{tabular}

Note: Data measures the year-to-date return

a. Climbed more than $37 \%$ in 2017, Vanguard Technology ETF is already up by $11.99 \%$ in 2018 .

b. Tech revenues are estimated to grow by $11.99 \%$ this year.

c. The balance sheet looks accurate with available cash balance and comparatively lower debt.

d. The tax cut and growth in wages make a positive impact on tech firms.

e. Increase dividend payments also increased share buybacks, limited available shares means - tech shares even more attractive (eg: Intel, Cisco, and Corning announced double-digit dividend increment).

\section{Financial Sectors}

\section{Recommendation 2: iShares US Financial ETFs}

\section{Financials}

\section{S\&P 500 INDEX}
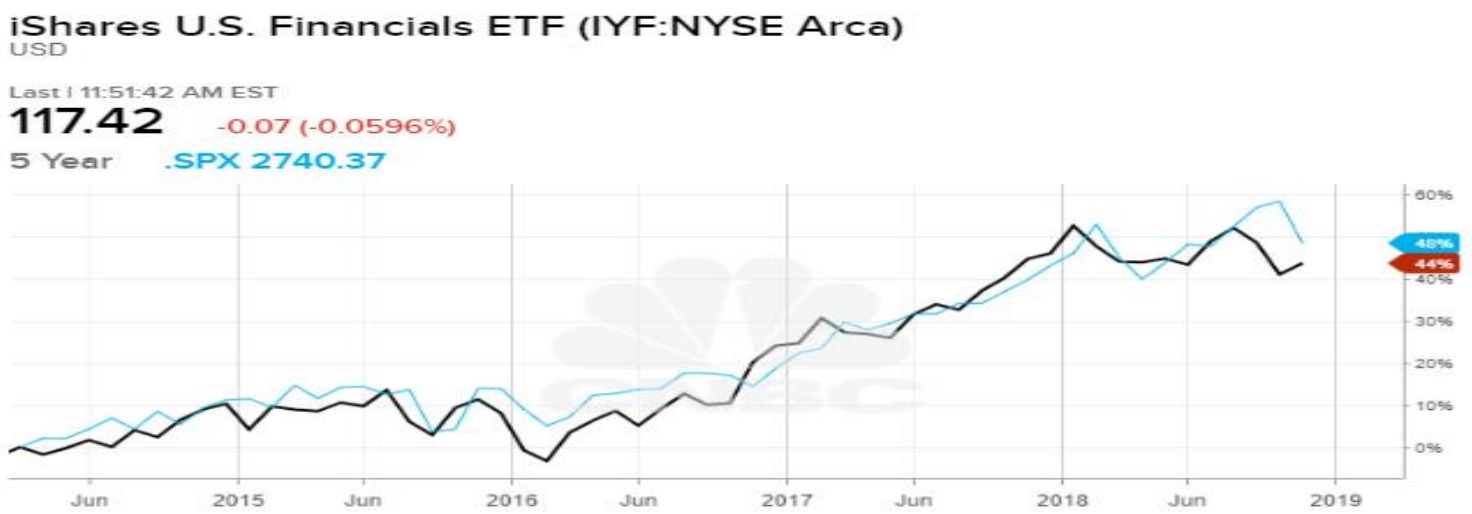

SECNEBC

There are some positive factors of the financial sector which are as below:

a. Diffidently increasing interest rate and dividend

b. Improving consumer finances

c. Reduced regulatory burden

d. At present situation, these positive factors will drive share prices iShares US Financial ETFs for the 6-month horizon. 


\section{Not Recommended 1: Utilities SPDR (XLU)}

Utility sectors contain stocks of utilities such as electric power, gas and water firms which require massive infrastructure, continuous upgrade, and regular maintenance. Since the Utility sector consistently underperforming against S\&P 500 in 2018 I do not recommend in my portfolio.

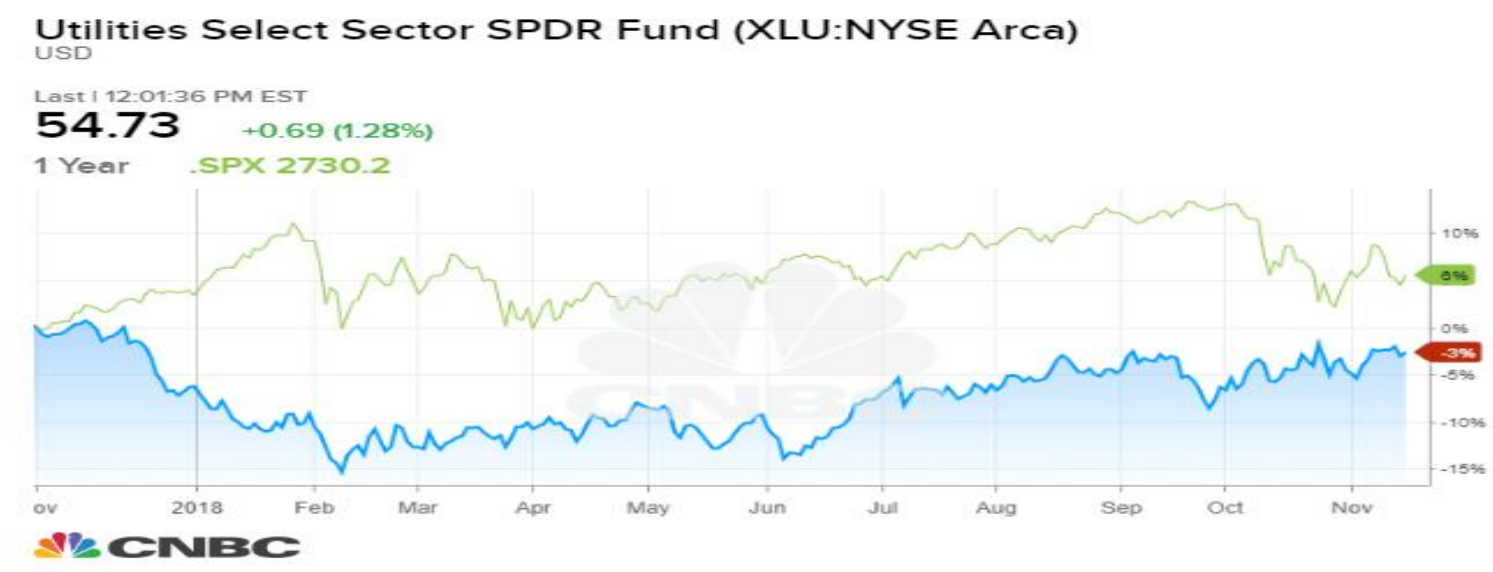

a. Rising Interest Rates are major problems

b. More Regulatory Restriction-Needs to meet Environmental Protection Agency regulation

c. Heavily rely on debt financing, may end up borrowing at a higher rate which results in steep debt-equity rations impacting firm's credit ratings

\section{Not Recommended 2: Consumer Staples-3 XLP Consumer Staples ETF}

a. Rising Interest Rates are major problems

b. Increased competition -low margin

c. Accommodative monetary policy/ Stimulative Fiscal Policy-Fed change in monitory/fiscal policy to stimulate the economy could hurt more- defensive sectors, like consumer staples.

\subsection{Income Generating}

By considering the basic characteristics of bonds, if the interest rates move higher, the value of the bonds will decline, others thing remaining same. However, bond with a short duration will have a low impact due to the change in interest rate. I am considering the duration of fewer than 6 months keeping out time horizon of 6 months, so I believe I will have a minimum risk by choosing short term bond as a low-risk income generating assets in my portfolio.

\section{Recommendation 1: SPDR SSgA Ultra Short-Term Bond ETF (ULST)}

a. This is an actively traded fund with an ultra-short duration.

b. Typically have a maturity less than one year

c. This protects investors from the imminent interest rate increase.

d. Usually called cash funds since their value is generally unaffected by changes in interest rates

e. $55 \%$ of this fund (as set) includes corporate sector, it also includes mortgage-backed, cash components and the government treasury.

f. Heavy corporate weight means it has a higher risk with a higher potential return than the US treasury. The overall rating is $\mathrm{A}+$.

\section{Recommendation 2: Vanguard Short-Term Bond ETF (BSV)}

a. BSV Short-term bonds ETF that is diverse but is more focused on US treasury (64\%).

b. IT has $65 \%$ credit quality at AAA.

c. Not Actively traded fund

d. Light on both interest and credit risk (Safest Assets)

\section{Not Recommended 1: TLO: SPDR Barclays Long Term Treasury ETF}

Since I expect a hike in interest rates over my investment horizon, I recommend against investing in Treasuries with long maturities and high duration. 


\section{Not Recommended 2: LWC: SPDR Barclays Capital Long Term Corporate Bond ETF}

I would avoid investing in this high duration corporate bond ETF based on current FED continuation for an upward revision in interest rates during 2018.

\subsection{Commodity}

Commodity faced a rough ride in 2017, proving a total return of $3 \%$ (very low compared to S \&P total return of $19 \%$ ). But 2018 could be a different story. The prices of commodities moved higher in 2018. Although commodity prices mostly reduced in November 2018 (energy and non-energy commodities falling 1.7\%). Furthermore, base and precious metals, along with energy commodities are expected of doing better in 2019. Analyzing the commodity markets, I recommend the following 2 ETFs. Energy prices are projected to be average 33\% higher in 2018 with the compared to 2017 and $13 \%$ higher from April 2018 and it will be stable in 2019. Nonenergy prices are projected to be roughly stable, gaining just under 2\% in 2018 and an additional 1\% in 2019, a modest downward revision from the April 2018 forecast.

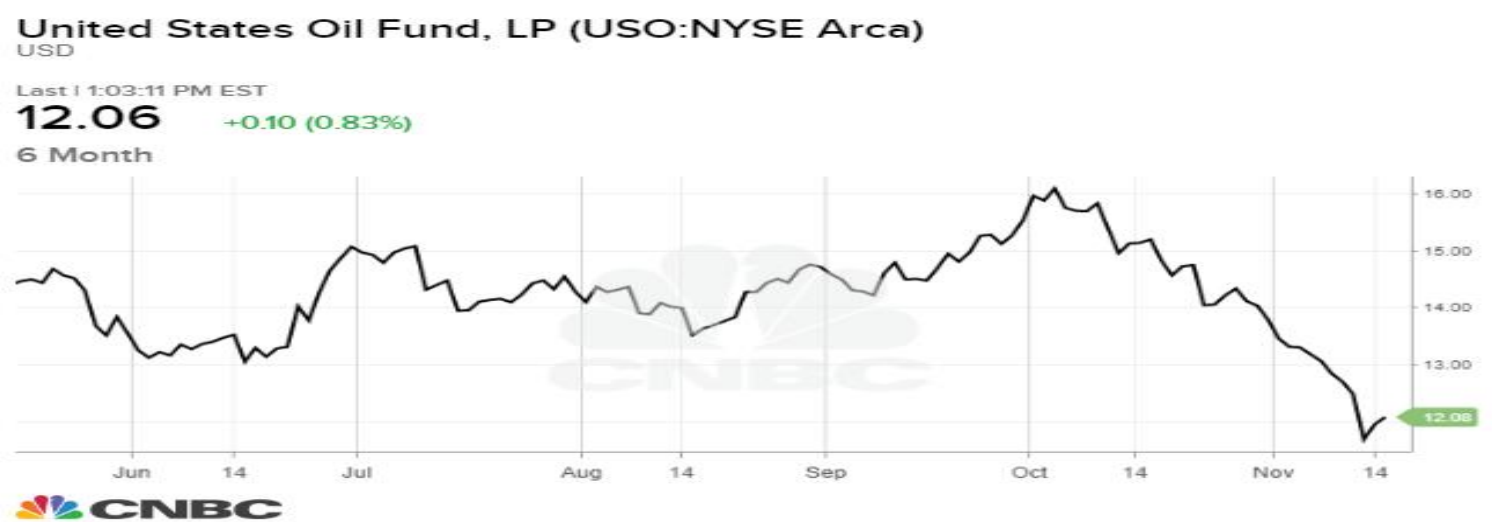

\section{Recommendation 1: United States Oil Fund (USO)}

This fund offers exposure to one of the most vital commodities, oil, \& potentially has appealas an inflation hedge. While oil may be appealing, USO often suffers from severe contango making the product more appropriate for short-term traders. The metal prices are projected to move higher in 2019 and, after that, it will be relatively stable, the prices of agriculture products are projected to be $2 \%$ in 2019.

I think the addition of this ETF in my portfolio would be a good choice as the oil market looks well in the next six months.

\section{Recommendation 2: PowerShares DB Agricultural Fund}

It provides a convenient and cost-effective way to invest in commodity futures. I think the addition of this ETF in my portfolio will provide diversification benefits.

I do not recommend investing in the United States Natural Gas Fund LP and PowerShares Dynamic Oil and Gas Services because of their high expenses and tight spreads.

\subsection{Emerging Markets}

I favor emerging market equities as I believe the recovery in emerging markets in 2018. After an impressive run in U.S. Stock markets, international stocks look reasonably priced in 2018. I believe emerging markets could be in the early stages of a multi-year recovery underpinned by growth acceleration, earnings revival, and att ractive valuations. However, I am aware of volatility, political and currency risk of investing in emerging markets. I recommend the following two emerging markets.

\section{Recommended 1: Turkey}

The iShares MSCI Turkey ETF pursues the result of investment that parallels to the performance of the MSCI Turkey Investable Market Index. It provides exposure to a broad range of company's in Turkey. Turkish government revealed 
strong economic growth this year and is expected that the strength will be maintained through out the year. So, I believe the inclusion of this ETF in my portfolio will be a good addition as it provides target access to Turkish Stocks.

\section{Recommended 2: India}

India has paved the way for stronger medium-term growth heading into 2018 after they saw major two reforms, demonetization and implementation of goods and services tax, the past year. Underlying consumer demand remained fairly strong despite GST related disruption, with the recovery taking place since October. Domestic consumption should continue to be robust, supported by wage growth, and relatively low inflation and interest rates. I may also see an increase in government spending in the run-up to the 2019 elections which should provide a further boost to growth.

I choose to invest Direxion Daily MSCI India Bull 3x ETF that plans for investing 80 percent of the assets in securities from the index and 20 percent in leverage the several instruments (financial). It focuses on large-cap and mid-cap stocks that will help to offset few risks.

I do not recommend investing in emerging markets Indonesia and Pakistan. Indonesia has one of the lowest tax charged in the globe that would hugely influence government financing to investment spending. Increased trade restrictions and geopolitical risk add another risk of investment in Indonesia. Pakistan, on the other hand, is on the verge of losing emerging market status. Shrinking turnover, illiquid financial markets, lack of trust of investors in financial markets and political risk makes Pakistan unappealing for the next six months.

\section{Strategic Asset Allocation (SAA)}

We assigned weights on the basis of my analysis of macroeconomic factors. Analyzing the next six month prospects of macroeconomic factors, I have tactical views on assets for the next six months.

a) Equity: As equity will show very good earnings momentum supported by corporate tax cuts and fiscal stimulus, I decide to overweight equity. I have a very positive view on technology and financial as well as value style factors. (Overweight)

b) Income generating: As I see rates rising moderately amid economic expansion and Fed normalization, I do not recommend long term bonds. However, I have positive views on shorter-term maturity bonds as they provide compelling risk/reward trade-off. (Underweight)

c) Commodities: I expect very good next six months for the commodity market. (Equal-weight)

d) Emerging or Frontier markets: As earnings momentum is rising over the year, I highly value emerging market stocks. I provide high weights for emerging market ETFs in my portfolio. (Overweight)

I have as signed weights to different asset classes as follows:

\begin{tabular}{|l|l|}
\hline Asset Class & Weights \\
\hline 1. US Equity & $\mathbf{3 0 \%}$ \\
\hline Vanguard Mega Cap Growth ETF (MGK) (Growth) & $60 \%$ \\
\hline Vanguard Mid-Cap Value ETF (Value) & $40 \%$ \\
\hline 2. Global Assets & $\mathbf{1 0 \%}$ \\
\hline India ETF- INDA iS hares MS CI India ETF & $50 \%$ \\
\hline ETF- Vanguard FTSE Europe ETF (VGX) & $50 \%$ \\
\hline 3. Sectors and Subsectors & $\mathbf{1 5 \%}$ \\
\hline Vanguard Technology ETF & $70 \%$ \\
\hline iShares US Financial ETFs & $30 \%$ \\
\hline 4. Income Generating & $\mathbf{5 \%}$ \\
\hline SPDRSSgA Ultra Short Term Bond ETF & $60 \%$ \\
\hline Vanguard Short-Term Bond ETF & $40 \%$ \\
\hline 5. Commodity & $\mathbf{1 0 \%}$ \\
\hline United States Oil Fund(USO) & $60 \%$ \\
\hline PowerShares DB Agricultural Fund & $40 \%$ \\
\hline 6. Emerging and Frontier Markets & $\mathbf{3 0 \%}$ \\
\hline The iShares MS CITurkey ETF & $50 \%$ \\
\hline Direxion Daily MSCIIndia Bull 3x ETF & $50 \%$ \\
\hline Total & $\mathbf{1 0 0 \%}$ \\
\hline
\end{tabular}


For the next six months, I believe, based on my analysis, US equity and emerging markets will perform very well. So, I have assigned a higher weight to US equity and emerging market. My holdings on Income generating is low due to the prospect of rising rates and tight spreads.

\section{References}

- Abeysekera, L., \& Dawson, P. (2014). Motivation and cognitive load in the flipped classroom: definition, rationale and a call for research. Higher Education Research \& Development, 1-14

- Bransford, J., Brown, A. L., \& Cocking, R. R. (Eds.) (2000) How People Learn: Brain, Mind, Experience, and School. Washington, DC: National Academy Press. Cinebell, Sharon K \& Cinebell, John M (2008). The Tension in Business Education between Academic Rigor and Real-World Relevance: The Role of Executive Professors. Academy of Management Learning \& Education, 7(1), 99. Crossref

- Edelson, D., (2001), Learning-for-Use: A Framework for the Design of Technology-Supported Inquiry. 84 Activities Journal of Research in Science Teaching 38(3), 355-385. Crossref

- Griffith, R. (2004). Knowledge production and the research-teaching nexus: the case of the built environment disciplines. Studies in Higher Education, 29 (6), pp. 709-726. Crossref

- Mogk, D. W. (2000) Bridges: Connecting Research and Education in the Earth System Sciences: Report to NSF Directorate for Geosciences. National Research Council (2007), Taking Science to School. National Academy Press, Washington, DC

- Seymour, E., and Hewitt, E. (1994) Talking About Leaving: Factors Contributing to High Attrition Rates Among Science, Mathematics, and Engineering Undergraduate Majors: Bureau of Sociological Research, Boulder, CO.

- Vygotsky, L.S. History of development of higher mental functions.// Coll. Op. to 6 tons. TZ / Editor. Ed. AV Zaporozhets. - M.: Education, 1983: 5-328.

- Zymnyia, 85 I.A. Educational Psychology: Studies Allowance 86. - Rostov n / D.: Publishing House «Phoenix», 1997, pp 400-473.

- Brownell, S. E. \& Tanner, K. D. 2012. Barriers to Faculty Pedagogical Change: Lack of training, time, incentives, and tensions with professional identity? CBE - Life Sciences Education, 11, 339-Life Sciences Education, 2012, Vol.11 (4), p.339-346.

- Gibbs, G. \& Coffey, M. 2004. The Impact of Training of University Teachers on their Teaching Skills, their Approach to Teaching and the Approach to Learning of their Students. Active learning 89 in Higher Education. 5 (1), $87-100$.

- Prince, M. 2004. Does Active Learning Work? A Review of the Research. Journal of Engineering Education, 93 (3), 223-231. Crossref

- Trigwell, K., Prosser, M. \& Waterhouse, f. 1999. Relations between teachers' approaches to teaching and students' approaches to learning. The International Journal of Higher Education and Educational Planning, 37, 57-70. 